\title{
Neuropsychiatric Lupus: Classification Criteria in Neuroimaging Studies
}

\author{
Tania M. Netto, Nicolle Zimmermann, Fernanda Rueda-Lopes, \\ Bernardo C. Bizzo, Rochele P. Fonseca, Emerson L. Gasparetto
}

\begin{abstract}
This systematic review described the criteria and main evaluations methods procedures used to classify neuropsychiatric systemic lupus erythematosus (NPSLE) patients. Also, within the evaluations methods, this review aimed to identify the main contributions of neuropsychological measurements in neuroimaging studies. A search was conducted in PubMed, EMBASE and SCOPUS databases with the terms related to neuropsychiatric syndromes, systemic lupus erythematosus, and neuroimaging techniques. Sixty-six abstracts were found; only 20 were completely analyzed and included. Results indicated that the 1999 American College of Rheumatology (ACR) criteria is the most used to classify NPSLE samples together with laboratorial, cognitive, neurological and psychiatric assessment procedures. However, the recommended ACR assessment procedures to classify NPSLE patients are being used incompletely, especially the neuropsychological batteries. Neuropsychological instruments and neuroimaging techniques have been used mostly to characterize NPSLE samples, instead of contributing to their classifications. The most described syndromes in neuroimaging studies have been seizure/cerebrovascular disease followed by cognitive dysfunctions as well as headache disorder.
\end{abstract}

RÉSUMÉ: Lupus neuropsychiatrique : critères de classification utilisés dans les études de neuroimagerie. Cette revue systématique décrit les critères et les principales méthodes d'évaluation utilisés pour classifier les patients atteints de lupus érythémateux aigu disséminé avec atteinte neuropsychiatrique (LÉADNP). Parmi les méthodes d'évaluation, cette revue a également pour objectif d'identifier les principales contributions des mesures neuropsychologiques dans les études de neuroimagerie. Nous avons effectué une recherche dans les bases de données PubMed, EMBASE et SCOPUS au moyen de mots clés en lien à des syndromes neuropsychiatriques, au lupus érythémateux aigu disséminé et aux techniques de neuroimagerie. Nous avons identifié 66 résumés dont seulement 20 ont été analysés complètement et inclus dans notre étude. Les résultats de cette analyse indiquent que les critères établis en 1999 par l'American College of Rheumatology (ACR) sont les plus utilisés pour classifier les échantillons de patients atteints de LÉADNP ainsi que les tests de laboratoire et les méthodes d'évaluation cognitive, neurologique et psychiatrique. Cependant, les critères recommandés par l'ACR pour classifier ces patient sont utilisés de façon incomplète, particulièrement les batteries neuropsychologiques. Les instruments neuropsycologiques et les techniques de neuroimagerie ont été utilisés surtout pour caractériser les échantillons de patients atteints de LÉADNP au lieu de servir à leur classification. Les syndromes les plus fréquemment décrits dans les études de neuroimagerie sont les crises convulsives/la maladie cérébrovasculaire suivies des dysfonctions cognitives et de la céphalée.

Can J Neurol Sci. 2013; 40: 284-291

Neuropsychiatric manifestations occur with frequency in systemic lupus erythematosus (NPSLE) ${ }^{1}$. However, attribution of these manifestations to SLE are considered one of the greatest challenges among behavioural and neuroimaging studies ${ }^{2}$. There still seems to be a long way towards a comprehension of the neuropsychiatric (NP) syndromes in SLE, even though the American College of Rheumatology (ACR) has started to facilitate and to enhance clinical research by developing standards for terminology, definitions and some assessment methods to describe $19 \mathrm{NP}$ syndromes in $\mathrm{SLE}^{3}$. Nevertheless, it is still quite a challenge to differentiate the NPSLE from the nonNPSLE, mainly due to the heterogeneity of assessments even after ACR recommendations, not sufficiently reported or unreported methods to classify each syndrome. American College of Rheumatology proposed nomenclature for NPSLE is mainly intended for didactic purposes, clinical research and reporting rather than clinical setting ${ }^{3}$. The general SLE is a recurrent, chronic, systemic, autoimmune disease which causes morbidity in between 161,000 to 322,000 adults $^{4}$. The NPSLE is a set of neurologic syndromes of the central and peripheral nervous system and/or of psychiatric syndromes observed in patients with SLE in which other causes are excluded ${ }^{3,5,6}$, by clinical, laboratory, neuroimaging and neuropsychological tests $^{3}$. These syndromes include twelve manifestations from the central nervous system, as follows, "aseptic meningitis, cerebrovascular disease, demyelinating syndrome, headache (including migraine and benign intracranial hypertension), movement disorder (chorea), myelopathy, seizure disorders, acute confusional state, anxiety disorder, cognitive dysfunction, mood disorder, psychosis" and seven manifestations related to the peripheral nervous system, "acute inflammatory demyelinating polyradiculoneuropathy (Guillain-Barré

From the 1Department of Radiology (TMN, FRL, BCB, ELG), Universidade Federal do Rio de Janeiro School of Medicine, Rio de Janeiro; 2Department of Psychology Human Cognition (NZ, RPF), Pontifical Catholic University of Rio Grande do Sul, Porto Alegre, Brazil.

Received August 27, 2012. Final Revisions Submitted November 26, 2012. Correspondence to: Tania M. Netto, Rua Mário Covas Jr. 135/907, Barra da Tijuca, Rio de Janeiro, RJ, Brazil. Email: tnetto@yahoo.com (T. Netto). 
syndrome), autonomic disorder, mononeuropathy, single/ multiplex, myasthenia gravis, neuropathy, cranial, plexopathy, polyneuropathy"3. The neuropsychiatric manifestations can occur as single or multiple events at any time during the course of SLE ${ }^{7}$. These manifestations have been considered very frequent among SLE patients, with occurrences varying from $57 \%$ to $91 \%$, being up to two-thirds of patients with this disease ${ }^{6-8}$. Among the 19 neuropsychiatric syndromes in SLE, the four most reported ones have been cognitive impairment (ranging from 70 to $80 \%$ ), mood disorders (from 60 to $70 \%$ ), headache (from 50 to $60 \%$ ) and cerebrovascular disease (from 20 to $40 \%)^{7,9,10}$. This variability is due, in part, to methodological differences among studies such as inclusion criteria of samples, type of design (retrospective), heterogeneous procedures of assessments and lack of reporting procedures ${ }^{6}$.

Neuroimaging techniques have been continually improving and ACR considers them to be important complementary tools for some case definitions in NPSLE and to rule out evidence of other disorders ${ }^{5,11}$, being useful for differential diagnosis. Some reviews have shown that advanced magnetic resonance imaging (MRI) techniques are able to detect white matter changes, which is frequently present in NPSLE ${ }^{1}$. However, advanced MRI techniques are still not clearly established as essential tools contributing to the diagnosis of NP syndromes in SLE ${ }^{12,13}$.

The ACR had also considered a neuropsychological battery based on formal instruments important to identify one of the most frequent syndromes, cognitive impairment, which also can contribute to the classification of NP in SLE. In spite of these recommendations by ACR, 1999, several studies have not presented homogeneity on this method of cognitive measurement ${ }^{10,12,14,15}$. Among the main advantages of using neuroimaging and neuropsychological tools for complementary diagnosis of NPSLE are that they can be non-invasive as well as sensitive in detecting central nervous system manifestations ${ }^{13}$.

The correct attribution of NP events to SLE or to other causes is still very challenging, and methodological approaches for assessment are a problem that still remain unresolved, lacking explicit case and terms definitions, comprehension of their pathogenesis, and pathognomonic tests findings, amongst other consequences that have been hampering the possibilities to compare results, reproduce methods, test hypotheses or conduct intervention studies ${ }^{3}$. Considering these difficulties, it seems very relevant to systematically review data generated in studies of neuropsychiatric syndromes classification in $\mathrm{SLE}^{2}$. Although the ACR system of classification for the 19 neuropsychiatric syndromes has been traditionally used, there still seems to be a lack of methodological homogeneity in the classification of NP in SLE.

In addition to the ACR consensus in 1999, as far as we know, only six general reviews or critical analyses have been published related to NPSLE ${ }^{7,12,16-19}$. However, none of them had systematically reviewed the factors contributing to inclusion criteria, sample's characteristics, assessment methods and heterogeneous outcomes, for NPSLE descriptions which consider neuroimaging studies.

The present systematic review aims to verify and to describe the criteria and main methods of assessment procedures employed to classify NP syndromes in SLE patients in neuroimaging studies. Also, within the assessment procedures, this review aims to identify the main contributions of neuropsychological tests in these neuroimaging studies. According to Popescu and Kao's ${ }^{20}$ review, the development of treatments for NPSLE is still a great challenge, due to the broad spectrum of manifestations of these syndromes and limitations in diagnostic tests. Since ACR considered neuroimaging evaluations important enough to change the direction and to enhance clinical investigations in NPSLE classification ${ }^{3}$, this systematic review may point out some important issues to better understand how neuroimaging study methods characterize and differentiate NPSLE from non-NPSLE samples. Regarding neuropsychological evaluations in neuroimaging studies, Borchers et al's ${ }^{13}$ review brings out two important issues that may limit improvements in NPSLE treatment: one is the limited knowledge of the pathophysiology of this disease and the other is the fact that patients have simultaneously more than one NP syndrome. These authors concluded that advances in neuroimaging technology and neuropsychological testing have been contributing to NPSLE diagnostic improvements and have allowed more effective interventions.

\section{METHOD}

This systematic review was based on a search in the PubMed, EMBASE and SCOPUS databases with the following search terms: ("neuropsychiatric syndromes") and ("systemic lupus erythematosus") and ("magnetic resonance imaging" or "MRI" or "magnetization transfer imaging" or "MTI" or "diffusionweighted imaging" or "DWI" or "diffusion tensor imaging" or "DTI" or "magnetic resonance spectroscopy" or "MRS" or "susceptibility weighted imaging" or "SWI" or "voxel-based morphometry" or "VBM" or "magnetoencephalography" or "MEG" or "electroencephalography" or "EEG" or "optical imaging" or "fNIRS" or "positron emission tomography" or "PET" or "single-photon emission computed tomography" or "SPECT" or "functional neuroimaging" or "fMRI" or "neuroimaging cortical thickness" or "default network" or "resting state" or "default mode network" or "volumetry"). Some filters were applied, only articles with adults, humans and

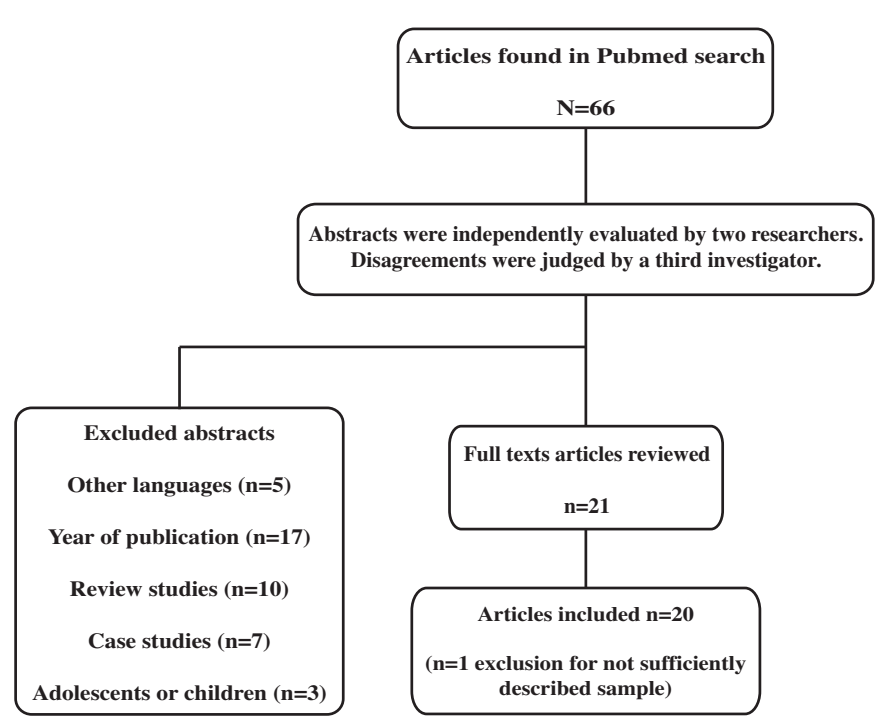

Figure: Fluxogram of reviewed NPSLE studies. 
Table 1: Characterization of criteria used and procedures for assessment of the samples

\begin{tabular}{|c|c|c|c|c|c|c|}
\hline \multirow[t]{2}{*}{ Reference } & \multirow[t]{2}{*}{ Criteria of characterization } & \multicolumn{5}{|c|}{ Procedures for criteria assessment } \\
\hline & & Clinical & Laboratorial & Cognitive & Neurological or neuroimaging & Psychiatric/Functional \\
\hline $\begin{array}{l}\text { Luyendijk et al. } \\
(2011)^{+}\end{array}$ & $\begin{array}{l}\text { ACR (1999) case definitions for NPSLE } \\
\text { syndromes assessed and classified by } 2 \\
\text { rheumatologists } \\
\text { NP symptoms were considered for NP- } \\
\text { SLE if one or more criteria was } \\
\text { accomplished }\end{array}$ & $\begin{array}{l}\text { Retrospectively assessed } \\
\text { by two rheumatologists }\end{array}$ & Described. & Not described. & $\begin{array}{l}\text { Lesions were categorized as } \\
\text { hyperintensities, parenchymal } \\
\text { defects, or areas of focal atrophy } \\
\text { through an MRI }\end{array}$ & Not described. \\
\hline Kozora et al. (2011)- & $\begin{array}{l}\text { Judgment by the patient's } \\
\text { rheumatologist to ensure no current or } \\
\text { prior important neuropsychiatry disorder } \\
\text { other than cognitive impairment }\end{array}$ & $\begin{array}{l}10-15 \text { minute interview } \\
\text { to ensure inclusion/ } \\
\text { exclusion criteria and a } \\
\text { structured psychiatric } \\
\text { interview to rule out } \\
\text { current depression }\end{array}$ & $\begin{array}{l}\text { Not } \\
\text { described. }\end{array}$ & The Cognitive Failures Questionnaire & $\begin{array}{l}10-15 \text { minute interview to ensure } \\
\text { inclusion/ exclusion criteria and a } \\
\text { structured psychiatric interview to } \\
\text { rule out current depression } \\
\text { Neurological Rating Scale }\end{array}$ & $\begin{array}{l}\text { Structured psychiatric interview } \\
10-15 \text { minute interview } \\
\text { to ensure inclusion/ exclusion criter } \\
\text { and a structured psychiatric intervie } \\
\text { rule out current depression }\end{array}$ \\
\hline Emmer et al. (2010)- & $\begin{array}{l}\text { ACR (1999) case definitions for NPSLE } \\
\text { syndromes assessed and classified by } \\
\text { one expert rheumatologists }\end{array}$ & $\begin{array}{l}\text { Assessment by specialist } \\
\text { for exclusion of } \\
\text { secondary causes of NP }\end{array}$ & Described. & Not described. & MRI & Not described. \\
\hline $\begin{array}{l}\text { Azarpazhooh et al. } \\
(2010)-\end{array}$ & $\begin{array}{l}\text { ACR (1999) case definitions for NPSLE } \\
\text { syndromes }\end{array}$ & $\begin{array}{l}\text { Review of medical } \\
\text { records }\end{array}$ & Described. & $\begin{array}{l}\text { Neuropsychological } \\
\text { Testing (Mini-mental State Examination (<24=moderate } \\
\text { cognitive impairment) } \\
\text { Bender-Gestalt test } \\
\text { Block Design (WAIS-R) }\end{array}$ & $\begin{array}{l}\text { Neurologic examination } \\
\text { MRI to verify the existence of } \\
\text { micro embolic signals }\end{array}$ & Not described. \\
\hline Cotton et al. (2004)+ & $\begin{array}{l}\text { ACR (1999) case definitions for NPSLE } \\
\text { syndromes }\end{array}$ & $\begin{array}{l}\text { Clinical exam and } \\
\text { eventual complementary } \\
\text { exams }\end{array}$ & Described. & Not described. & MRI and clinical neuropsychiatric & Clinical neuropsychiatric \\
\hline Wilmer et al. (2003)+ & $\begin{array}{l}\text { ACR (1999) case definitions for NPSLE } \\
\text { syndromes }\end{array}$ & Not described. & $\begin{array}{l}\text { Not } \\
\text { described. }\end{array}$ & $\begin{array}{l}\text { Mini-Mental State } \\
\text { Examination }\end{array}$ & $\begin{array}{l}\text { Neuro-SLEDAI } \\
\text { Neuro-SLICC }\end{array}$ & Not described. \\
\hline $\begin{array}{l}\text { Whitelaw \& } \\
\text { Spangenberg (2009)- }\end{array}$ & $\begin{array}{l}\text { Exclusion of all criteria for NPSLE } \\
\text { except for headache. }\end{array}$ & Not described. & $\begin{array}{l}\text { Not } \\
\text { described. }\end{array}$ & $\begin{array}{l}\text { Wechsler Adult Intelligence Scale; } \\
\text { Wechler Memory Scale - Logical Memory; visual } \\
\text { memory; Associated } \\
\text { Learning - Easy; Associated learning - difficult; Reye } \\
\text { Complex figure recall; } \\
\text { Stroop color word interference test } \\
\text { and Auditory Verbal Learning Test }\end{array}$ & $\begin{array}{l}\text { Assessment of headache according } \\
\text { to International Headache Society } \\
\text { criteria }\end{array}$ & $\begin{array}{l}\text { Assessment of psychiatric sympton } \\
\text { the criteria from American Psychial } \\
\text { Association }\end{array}$ \\
\hline Harboe et al. (2008)+ & $\begin{array}{l}\text { ACR (1999) case definitions for NPSLE } \\
\text { syndromes } \\
\text { Systemic Lupus assessed in a consensus } \\
\text { meetings }\end{array}$ & $\begin{array}{l}\text { Review of the medical } \\
\text { history } \\
\text { Clinical examination by } \\
\text { a specialist in internal } \\
\text { medicine } \\
\text { Clinical interview }\end{array}$ & Described. & $\begin{array}{l}\text { Assessment by a specialist in neuropsychology: Trail } \\
\text { Making Test, Category Test, Seashore Rhythm Test, } \\
\text { Lafayette Hand Dynamometer Test, Finger Tapping Test, } \\
\text { Tactual Performance Test, Lafayette Grooved Pegboard } \\
\text { Test, Wechsler Adult Intelligence Scale (WAIS), Wechsler } \\
\text { Memory Scale Revised, Wisconsin Card Sorting Test, FAS } \\
\text { Verbal Fluency test, and Stroop Colour-Word Interference } \\
\text { Test. }\end{array}$ & $\begin{array}{l}\text { Neurological assessment } \\
\text { Nerve conduction studies (NCS) }\end{array}$ & $\begin{array}{l}\text { Short Form-36 } \\
\text { Fatigue Severity Scale } \\
\text { Fatigue Visual Analogue Scale } \\
\text { Beck Depression Inventory }\end{array}$ \\
\hline Emmer et al. (2008)+ & $\begin{array}{l}\text { ACR (1999) case definitions for NPSLE } \\
\text { syndromes } \\
\text { Diagnosed by an experienced } \\
\text { rheumatologist }\end{array}$ & Not described. & Described. & Not described. & Not described. & Not described. \\
\hline Cho et al. (2007)+ & $\begin{array}{l}\text { ACR (1999) case definitions for NPSLE } \\
\text { syndromes }\end{array}$ & $\begin{array}{l}\text { Retrospective clinical } \\
\text { assessment of medical } \\
\text { records }\end{array}$ & Described. & Not described. & Not described. & Not described. \\
\hline Roldan et al. (2006)- & $\begin{array}{l}\text { Detailed prospectively collected NPSLE } \\
\text { and SLE histories were available }\end{array}$ & $\begin{array}{l}\text { Clinical evaluation for } \\
\text { general health }\end{array}$ & Described. & Not described. & $\begin{array}{l}\text { Brain MRI to detect focal and non- } \\
\text { focal injuries } \\
\text { Color Doppler TEE to detect left- } \\
\text { sided VHD } \\
\text { other cardiac or aortic substrates for } \\
\text { embolism } \\
\text { Neuropsychiatric evaluation }\end{array}$ & Neuropsychiatric evaluation \\
\hline $\begin{array}{l}\text { Tatsukawa et al. } \\
\text { (2005)- }\end{array}$ & $\begin{array}{l}\text { The CNS involvement was previously } \\
\text { assessed by clinical symptoms such as } \\
\text { organic brain syndrome seizures, } \\
\text { cerebral infarction and psychiatric } \\
\text { disorder. }\end{array}$ & $\begin{array}{l}\text { Clinical assessment of } \\
\text { CNS involvement }\end{array}$ & Described. & Not described. & Not described. & Not described. \\
\hline $\begin{array}{l}\text { Lampropoulos et al. } \\
(2005)^{+}\end{array}$ & Not utilized & Clinical interview & Described. & Not described. & EEG & Reported neuropsychiatric sympton \\
\hline Davey et al. $(2010)+$ & $\begin{array}{l}\text { ACR (1999) case definitions for NPSLE } \\
\text { syndromes }\end{array}$ & Clinical interview & Described. & $\begin{array}{l}\text { Repeatable Battery for the Assessment of } \\
\text { Neuropsychological Status considering cognitive } \\
\text { dysfunction with at least one impaired function }\end{array}$ & $\begin{array}{l}\text { Evaluated by experienced } \\
\text { neurologist }\end{array}$ & Not described. \\
\hline Sanna et al. (2003)+ & $\begin{array}{l}\text { ACR (1999) case definitions for NPSLE } \\
\text { syndromes }\end{array}$ & $\begin{array}{l}\text { Clinical NP } \\
\text { questionnaire }\end{array}$ & Described. & $\begin{array}{l}\text { One hour neuropsychological battery: Trail Making Test, } \\
\text { Letter-Number Sequencing, Logical Memory, Rey- } \\
\text { Osterrieth Complex } \\
\text { Figure Test (copy, immediate recall, and delayed recall), } \\
\text { Controlled Oral } \\
\text { Word Association Test (COWAT/FAS), Animal Naming } \\
\text { Test, Digit Symbol } \\
\text { Substitution Test, and Stroop Color and Word Test in order } \\
\text { to document } \\
\text { deficits in any or all of the following cognitive domains: } \\
\text { Simple attention, } \\
\text { Complex attention/Executive functions, Memory, Visual- } \\
\text { spatial } \\
\text { processing, Language, Psychomotor speed, and Motor } \\
\text { function. Premorbid IQ was estimated by means of the } \\
\text { National Adult Reading Test }\end{array}$ & $\begin{array}{l}\text { Questionnaire prepared with } \\
\text { particular attention to history and } \\
\text { objectively documented NP } \\
\text { manifestations. }\end{array}$ & $\begin{array}{l}\text { Questionnaire prepared with particı } \\
\text { attention to history and } \\
\text { objectively documented NP } \\
\text { manifestations. }\end{array}$ \\
\hline Ainiala et al. (2004)+ & $\begin{array}{l}\text { ACR (1999) case definitions for NPSLE } \\
\text { syndromes } \\
\text { According to the clinical impression of } \\
\text { one evaluator }\end{array}$ & $\begin{array}{l}\text { Clinical assessment and } \\
\text { examination records of } \\
\text { medical history, clinical } \\
\text { examination, review of } \\
\text { medical records }\end{array}$ & Described. & Neuropsychological assessment not described in this paper & Not described. & SLICC. \\
\hline $\begin{array}{l}\text { Walecki et al. (2002)- } \\
\text { Kumral et al. (2002)- }\end{array}$ & $\begin{array}{l}\text { American Rheumatological Association } \\
\text { ACR (1999) case definitions for NPSLE } \\
\text { syndromes }\end{array}$ & $\begin{array}{l}\text { Not described. } \\
\text { Physical examination }\end{array}$ & $\begin{array}{l}\text { Described. } \\
\text { Described. }\end{array}$ & $\begin{array}{l}\text { Not described. } \\
\text { Neuropsychological tests with stablished cut-off points for } \\
\text { deficits based on normative data. Atenttion - Digit Span } \\
\text { Test; Global Cognitive function - Mini-Mental state Exame; } \\
\text { Rey Auditory Verbal Learning Test; } \\
\text { Visual Memory - } \\
\text { Rey Visual Design Learning Test; } \\
\text { Stroop test } \\
\text { Raven's Colored progressive Matrices }\end{array}$ & $\begin{array}{l}\text { Not described. } \\
\text { Neurological examination }\end{array}$ & $\begin{array}{l}\text { Not described. } \\
\text { Depression and Psychosis were ass } \\
\text { according with DSM-IV. }\end{array}$ \\
\hline Karassa, et al. $(2000)+$ & $\begin{array}{l}\text { Neuropsychiatric syndromes by } \\
\text { rheumatologist and neurologist staff } \\
\text { Adapted ACR (1999) case definitions } \\
\text { for NPSLE syndromes }\end{array}$ & $\begin{array}{l}\text { Follow-up, observation } \\
\text { and clinical evaluations }\end{array}$ & Described. & Not described. & EEG & Not described. \\
\hline $\begin{array}{l}\text { Podrazilová et al. } \\
\text { (2008) }\end{array}$ & ACR (1999) criteria & $\begin{array}{l}\text { Review of medical } \\
\text { records }\end{array}$ & Described. & Not described. & MRI & Not described. \\
\hline
\end{tabular}

Note. +studies that characterize the participants according to the 19 ACR neuropsychiatric syndromes; - studies that do not characterize the sample according to the neuropsychiatric syndromes; NP= Neuropsychiatric; WAIS-R= Wechsler Adult Intelligence Scale-Revised; SLEDAI =Disease Activity Index; SLICC = The Systemic Lupus International Collaborating Clinics; DSM= Diagnostic and Statistical Manual of Mental Disorders; EEG=electroencephalogram; MRI=magnetic resonance imaging; TEE=Transesophageal echocardiography; VHD=Valvular heart disease. 
Table 2: Characterization of neuroimaging studies: aim and methods

\begin{tabular}{|c|c|c|c|c|}
\hline Reference & Aim & Study design & Sample & Neuroimaging \\
\hline $\begin{array}{l}\text { Luyendijk et al. } \\
\text { (2011) }\end{array}$ & $\begin{array}{l}\text { To provide an inventory of brain abnormalities on conventional } \\
\text { MRI in NPSLE and to interpret pathogenetic mechanisms. }\end{array}$ & $\begin{array}{l}\text { Observational } \\
\text { retrospective }\end{array}$ & Active NPSLE patients $(\mathrm{n}=74)$ & $\begin{array}{l}\text { MRI (T1- and T2-weighted images and either proton } \\
\text { density-weighted or FLAIR in the axial plane) }\end{array}$ \\
\hline $\begin{array}{l}\text { Kozora et al. } \\
(2011)\end{array}$ & $\begin{array}{l}\text { To examine hippocampal volumes and neurometabolic } \\
\text { alterations in relation to memory in non-NPSLE. }\end{array}$ & $\begin{array}{l}\text { Comparative } \\
\text { prospective }\end{array}$ & $\begin{array}{l}\text { Non-NPSLE patients }(\mathrm{n}=81) \\
\text { Healthy controls }(\mathrm{n}=34)\end{array}$ & $\begin{array}{l}\text { Volumetric MRI and MRS of the right and left } \\
\text { hippocampal areas (right and left) }\end{array}$ \\
\hline $\begin{array}{l}\text { Emmer et al. } \\
(2010)\end{array}$ & $\begin{array}{l}\text { To quantify any perfusion abnormalities and to determine their } \\
\text { contribution to NPSLE. }\end{array}$ & Comparative & $\begin{array}{l}\text { Active NPSLE patients }(\mathrm{n}=15) \\
\text { Inactive NPSLE patients }(\mathrm{n}=26) \\
\text { Control subjects }(\mathrm{n}=11)\end{array}$ & $\begin{array}{l}\text { Cerebral blood flow } \\
\text { Cerebral blood volume } \\
\text { Mean transit time } \\
\text { MRI } \\
\text { Bolus-tracking perfusion MRI }\end{array}$ \\
\hline $\begin{array}{l}\text { Azarpazhooh et } \\
\text { al. (2010) }\end{array}$ & $\begin{array}{l}\text { To clarify the pathophysiology of the CNS involvement in } \\
\text { SLE. }\end{array}$ & Prospective & $\begin{array}{l}\text { Patients with SLE }(\mathrm{n}=68) \text {, NPSLE } \\
(\mathrm{n}=24) \text { and non-NPSLE }(\mathrm{n}=44)\end{array}$ & Transcranial Doppler (middle cerebral arteries) \\
\hline $\begin{array}{l}\text { Davey et al. } \\
(2010)\end{array}$ & To investigate the role of CED in SLE and in NPSLE. & Comparative & $\begin{array}{l}\text { Patients with SLE }(\mathrm{N}=61) \\
\text { Control subjects }(\mathrm{N}=70)\end{array}$ & $\begin{array}{l}\text { Transcranial Doppler Ultrasonography (middle } \\
\text { central artery) }\end{array}$ \\
\hline $\begin{array}{l}\text { Whitelaw and } \\
\text { Spangenberg } \\
\text { (2009) }\end{array}$ & $\begin{array}{l}\text { To investigate the possible association between impaired } \\
\text { cognitive function and chronic headache in SLE. }\end{array}$ & Comparative & $\begin{array}{l}\text { Patients with SLE but without the } \\
\text { antiphospholipid }(\mathrm{n}=61) \text {, no headaches } \\
\text { group }(\mathrm{n}=21) \text {, migrainous headaches } \\
(\mathrm{n}=19) \text {, aura }(\mathrm{n}=11) \text {, other headaches } \\
(\mathrm{n}=11) \text {, tension type headaches }(\mathrm{n}=7)\end{array}$ & $\begin{array}{l}\text { MRI using gadolinium (Ventriculo-brain ratios was } \\
\text { calculated) }\end{array}$ \\
\hline $\begin{array}{l}\text { Harboe et al. } \\
(2008)\end{array}$ & $\begin{array}{l}\text { To compare the prevalence and pattern of NPSLE to Primary } \\
\text { Sjögren syndrome using the ACR criteria. }\end{array}$ & Comparative & $\begin{array}{l}\text { Patients with SLE }(\mathrm{n}=68) \\
\text { Patients with Primary Sjögren } \\
\text { syndrome }(\mathrm{n}=72)\end{array}$ & MRI \\
\hline $\begin{array}{l}\text { Emmer et al. } \\
\text { (2008) }\end{array}$ & $\begin{array}{l}\text { To investigate if, in NPSLE patients, MTR histogram } \\
\text { parameters are related to neurochemical findings from proton } \\
\text { MRS and to determine whether MTR changes are specific to } \\
\text { NPSLE. }\end{array}$ & Comparative & $\begin{array}{l}\text { SLE patients }(\mathrm{n}=18) \\
\text { NPSLE patients }(\mathrm{n}=34) \\
\text { Healthy controls }(\mathrm{n}=15)\end{array}$ & $\begin{array}{l}\text { MRI (Axial T1-weighted spin-echo, axial slices) } \\
\text { MTI (3-dimensional gradient-echo pulse, axial } \\
\text { slices) 1 H-MRS (Single-voxel) with double spin- } \\
\text { echo point-resolved spectroscopy sequence }\end{array}$ \\
\hline $\begin{array}{l}\text { Podrazilová et } \\
\text { al. (2008) }\end{array}$ & $\begin{array}{l}\text { To determine the volume of pathological foci in the brain tissue } \\
\text { of NPSLE and non-NPSLE patients and to find out if that } \\
\text { volume depends on clinical records. }\end{array}$ & Comparative & $\begin{array}{l}\text { Patients with NPSLE }(\mathrm{n}=29) \\
\text { Participants without }(\mathrm{n}=24) \\
\text { Healthy controls }(\mathrm{n}=16)\end{array}$ & Volumetric MRI in FLAIR \\
\hline $\begin{array}{l}\text { Cho et al. } \\
(2007)\end{array}$ & $\begin{array}{l}\text { To compare clinical manifestations, brain MRI findings and } \\
\text { prognosis of NPSLE and NBD. }\end{array}$ & Comparative & $\begin{array}{l}\text { Patients with NPSLE }(\mathrm{n}=25) \\
\text { Patients with NBD }(\mathrm{n}=18)\end{array}$ & $\begin{array}{l}\text { MRI (T1-wighted images, T2-weighted images and } \\
\text { FLAIR). }\end{array}$ \\
\hline $\begin{array}{l}\text { Roldan et al. } \\
\text { (2006) }\end{array}$ & $\begin{array}{l}\text { To determine whether VHD and brain injury are associated } \\
\text { with nonfocal NPSLE. }\end{array}$ & Comparative & $\begin{array}{l}\text { Patients with nonfocal } \\
\text { NPSLE }(\mathrm{n}=18) \\
\text { Patients with non-NPSLE }(\mathrm{n}=10) \\
\text { Healthy controls }(\mathrm{n}=28)\end{array}$ & $\begin{array}{l}\text { MRI (T1-weighted volume, T2-weighted axial series, } \\
\text { DWI series and a FLAIR) }\end{array}$ \\
\hline $\begin{array}{l}\text { Tatsukawa et al. } \\
(2005)\end{array}$ & $\begin{array}{l}\text { To evaluate the usefulness of the average amount of CBF for } \\
\text { NPSLE. }\end{array}$ & Correlational & $\begin{array}{l}\text { Patients NPSLE }(\mathrm{n}=16) \\
\text { Patients non-NPSLE }(\mathrm{n}=57)\end{array}$ & SPECT (rCBF and BPI values were evaluated) \\
\hline $\begin{array}{l}\text { Lampropoulos } \\
\text { et al. (2005) }\end{array}$ & $\begin{array}{l}\text { To describe the prevalence and clinical associations of } \\
\text { abnormalities on EEG in patients with APS and/or NPSLE. }\end{array}$ & $\begin{array}{l}\text { Comparative, } \\
\text { descriptive and } \\
\text { correlational }\end{array}$ & $\begin{array}{l}\text { APS with NPSLE }(\mathrm{n}=14) \\
\text { NPSLE without aPL } \\
(\mathrm{n}=19)\end{array}$ & $\begin{array}{l}\text { EEG (electrodes were positioned according to the } \\
\text { international } 10-20 \text { system, and standard recordings } \\
\text { were performed for } 15-20 \text { minutes during relaxed } \\
\text { wakefulness, with sessions of overbreathing and } \\
\text { photic stimulation) }\end{array}$ \\
\hline $\begin{array}{l}\text { Cotton et al. } \\
(2004)\end{array}$ & $\begin{array}{l}\text { To evaluate with high-field MRI the CNS involvement in a } \\
\text { series of SLE patients with or without NPSLE and to detect a } \\
\text { possible relationship between MRI and clinical parameters. }\end{array}$ & $\begin{array}{l}\text { Comparative } \\
\text { retrospective }\end{array}$ & $\begin{array}{l}\text { Patients with a SLE }(\mathrm{n}=58) \\
\text { Patients with NPSLE }(\mathrm{n}=30) \\
\text { Patients with non-NPSLE }(\mathrm{n}=28) \\
\text { Healthy controls }(\mathrm{n}=18)\end{array}$ & $\begin{array}{l}\text { MRI (including diffusion weighted-images, high- } \\
\text { resolution 3D T1 weighted-images) }\end{array}$ \\
\hline $\begin{array}{l}\text { Ainiala et al. } \\
\text { (2004) }\end{array}$ & $\begin{array}{l}\text { To evaluate whether serum matrix metalloproteinase } 9 \text { levels } \\
\text { are associated with NPSLE, particularly cognitive dysfunction, } \\
\text { evaluated by neuropsychological tests and MRI. }\end{array}$ & $\begin{array}{l}\text { Comparative } \\
\text { prospective }\end{array}$ & $\begin{array}{l}\text { Healthy controls }(\mathrm{N}=43) \\
\text { Patients with SLE }(\mathrm{N}=44)\end{array}$ & $\begin{array}{l}\text { MRI (sagittal T1-weighted, axial T1-weighted, axial } \\
\text { T2-weighted, and coronal FLAIR sequences; axial 3- } \\
\text { dimensional T2 fast spin-echo and } \\
\text { gadoliniumdiethylenetriaminepentaacetic acid- } \\
\text { enhanced 3-D T1 spoiled gradient-echo images). }\end{array}$ \\
\hline $\begin{array}{l}\text { Sibbit et al. } \\
(2003)\end{array}$ & $\begin{array}{l}\text { To compare FLAIR imaging with proton density/T2 weighted } \\
\text { (PD/T2) imaging in NPSLE. }\end{array}$ & Comparative & $\begin{array}{l}\text { Patients with NPSLE }(\mathrm{n}=28) \\
\text { Healthy controls }(\mathrm{n}=25)\end{array}$ & $\mathrm{MRI}(\mathrm{T} 1, \mathrm{PD} / \mathrm{T} 2$, and FLAIR) \\
\hline $\begin{array}{l}\text { Sanna et al. } \\
\text { (2003) }\end{array}$ & $\begin{array}{l}\text { To apply the new ACR nomenclature for NPSLE, to determine } \\
\text { the prevalence of the different NPSLE and to evaluate which of } \\
\text { these manifestations correlate with APL }\end{array}$ & $\begin{array}{l}\text { Descriptive, } \\
\text { correlational }\end{array}$ & 323 patients with SLE & MRI (standard spin-echo technique). \\
\hline $\begin{array}{l}\text { Walecki et al. } \\
(2002)\end{array}$ & $\begin{array}{l}\text { To determine the value of modern imaging techniques (MR } \\
\text { sequences - FLAIR, DWI) in the diagnosis of cerebral changes } \\
\text { in NPSLE. }\end{array}$ & Observational & $\begin{array}{l}\text { Patients with neurological symptoms of } \\
\text { SLE }(\mathrm{N}=50)\end{array}$ & $\begin{array}{l}\text { MRI (SE, FSE, FAST, FLAIR sequences and in } 12 \\
\text { cases also in EPI DWI sequences; T1 and T2- } \\
\text { weighted images in sagittal and transverse planes } \\
\text { were analysed) }\end{array}$ \\
\hline $\begin{array}{l}\text { Kumral et al. } \\
\text { (2002) }\end{array}$ & $\begin{array}{l}\text { To investigate the association of microembolic signals with } \\
\text { NPSLE manifestations and to compare the results with those } \\
\text { from patients non-NPSLE and normal controls. }\end{array}$ & Comparative & $\begin{array}{l}\text { Patients patients with SLE }(\mathrm{N}=53) \\
\text { Normal controls }(\mathrm{N}=50)\end{array}$ & $\begin{array}{l}\text { MRI and/or MRA } \\
\text { Extracranial Doppler } \\
\text { Transcranial Doppler } \\
\text { Sonography } \\
\text { Duplex sonography } \\
\text { Electrocardiography } \\
\text { Transthoracic/transesophageal Echocardiography }\end{array}$ \\
\hline $\begin{array}{l}\text { Karassa et al. } \\
(2000)\end{array}$ & $\begin{array}{l}\text { To identify variables that are associated with the evolution of } \\
\text { cerebral changes on sequential MRI scans as well as with } \\
\text { clinical outcomes in NPSLE. }\end{array}$ & $\begin{array}{l}\text { Observational } \\
\text { prospective, } \\
\text { follow-up }\end{array}$ & $\begin{array}{l}\text { Patients with SLE (including } 14 \text { with } \\
\text { the APS) who had been hospitalized } \\
\text { with primary NP disease ( } \mathrm{n}=32 \text { ) }\end{array}$ & $\begin{array}{l}\text { MRI (T1-weighted } 600 / 20 \mathrm{~ms} \text { and double echo } \\
\text { proton density T2- } \\
\text { weighted } 2,500 / 30 / 90 \mathrm{~ms} \text {, axial and coronal scans). }\end{array}$ \\
\hline
\end{tabular}

Note. Neuro Behçet's disease (NBD); Cerebral Blood Flow (CBF); antiphospholipid syndrome (APS); cerebrovascular endotelial dysfunction (CED); antiphospholipid antibodies (aPL); Magnetic resonance imaging (MRI); Non-neuropsychiatric systemic lupus erythematosus (non-NPSLE); neuropsychiatric systemic lupus erythematosus (NPSLE); Fluid Attenuated Inversion Recovery (FLAIR); systemic lupus erythematosus (SLE); fast spin echo (FSE); diffusion weighted imaging (DWI); magnetization transfer ratio (MTR); fast spin echo (FAST); valvular heart disease (VHD); antiphospholipid syndrome (APS).

those published in English, French, Spanish, or Portuguese were reviewed. Repeated articles and papers published before 2000 were excluded because they occurred prior to the ACR classification criteria. Sixty six articles were reviewed manually, resulting in 21 full text reviewed papers, after exclusion criteria analysis. Abstracts were excluded for not having included at least one group with NPSLE, not using at least one neuroimaging technique as a tool for assessment, not being empirical, and with single or multiple case studies. The systematic review fluxogram can be viewed in the Figure.

\section{RESULTS}

Table 1 presents the characterization of adopted criteria and procedures for each article. The majority of studies (70\%) classified NPSLE according to ACR recommendations. However, a great number of them did not use all ACR 
recommendations. Most of them used laboratorial (85\%), clinical (75\%) and neurological/neuroimaging (60\%) assessments and less than half used cognitive (45\%) and psychiatric/functional evaluations (40\%).

Table 2 characterizes each study included in this systematic review according to their aim, design, sample distribution, main features and administered neuroimaging techniques for brain structure or function measurement as dependent variables. Regarding their aims, $70 \%$ of the studies used neuroimaging

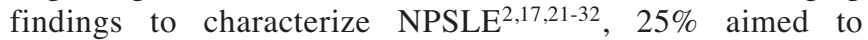
investigate the relationship between clinical and neuroimaging findings of this population ${ }^{26,29,31,33,34}, 20 \%$ investigated technological issues of neuroimaging tools to identify NPSLE ${ }^{25,35-37}$, and $15 \%$ searched for both neuroimaging and cognitive findings to describe SLE in general ${ }^{17,23,30}$. The majority of samples analyzed included two groups, general SLE patients compared to healthy controls $(20 \%)^{17,22,30,32}$ or NPSLE compared to a non-NPSLE $(15 \%)^{21,28,35}$. Moreover, two groups continue to be compared, but in these studies NPSLE were compared with other diseases $(10 \%)^{27,33}$, NPSLE with healthy controls $(10 \%)^{18,36}$, general SLE with other disorders $(5 \%)^{24}$. Finally, a few studies had only one group of NPSLE patients $(15 \%)^{2,34,37}$. In this way, $70 \%$ of these studies had a comparative $\operatorname{design}{ }^{15,17,22-28,30-33,36}$. The most common neuroimaging techniques to measure brain structure or function as dependent variables were MRI $(75 \%)^{2,17,18,23-32,34,37}$, then transcranial Doppler $(15 \%)^{21,22,32}$, MRS $(10 \%)^{17,25}$, and the following techniques, MTI, SPECT, EEG and extracranial Doppler, with $5 \%$ each.

In Table 3 it can be observed that only 14 of 20 articles, included in this analysis, had cited specifically the 19 neuropsychiatric syndromes. It also shows the ten most prevalent

Table 3: The four neuropsychiatric (NP) manifestations most prevalent in patients with SLE according to ACR case definitions for NPSLE

\begin{tabular}{|c|c|c|c|c|c|}
\hline References & $\begin{array}{l}\text { NPSL } \\
\mathrm{E}(\mathrm{n}=)\end{array}$ & $\begin{array}{l}\text { Four most prevalent ACR } \\
\text { criteria for NPSLE - } \\
\text { Peripheral Nervous System } \\
\text { (PNS) }\end{array}$ & $\mathrm{n}(\%)$ & Four most prevalent ACR criteria for NPSLE - Central Nervous System (CNS) & $\mathrm{n}(\%)$ \\
\hline \multirow{4}{*}{ 1-Luyendijk et al. (2011) } & \multirow{4}{*}{74} & \multirow{4}{*}{$\begin{array}{l}\text { Not included as the four most } \\
\text { prevalent ACR criteria for } \\
\text { NPSLE }\end{array}$} & & Headache disorders & $27(36.4)$ \\
\hline & & & & Seizure disorder & $19(25.6)$ \\
\hline & & & & Cognitive dysfunction & $16(21.6)$ \\
\hline & & & & Psychosis & $13(17.5)$ \\
\hline \multirow{5}{*}{$\begin{array}{l}\text { 2-Azarpazhooh et al. (2010)- } \\
\text { 3-Davey et al. (2010)+ }\end{array}$} & \multirow{5}{*}{$\begin{array}{l}24 \\
61\end{array}$} & \multirow{5}{*}{$\begin{array}{l}\text { Not described } \\
\text { Not included as the four most } \\
\text { prevalent ACR criteria for } \\
\text { NPSLE }\end{array}$} & & \multicolumn{2}{|l|}{ Not described } \\
\hline & & & & Headache disorder & $55(90)$ \\
\hline & & & & Cognitive dysfunction & $27(45)$ \\
\hline & & & & Mood disorder & $24(39)$ \\
\hline & & & & Cerebrovascular disease & $13(21)$ \\
\hline \multirow[t]{4}{*}{ 4-Emmer et al. (2010)- } & \multirow[t]{4}{*}{15} & \multirow{4}{*}{$\begin{array}{l}\text { Not included as the four most } \\
\text { prevalent ACR criteria for } \\
\text { NPSLE }\end{array}$} & & Cerebrovascular Disease & $12(80)$ \\
\hline & & & & Cognitive Dysfunction & $11(73.3)$ \\
\hline & & & & Headache disorders & $10(66.6)$ \\
\hline & & & & Seizure disorder & $10(66.6)$ \\
\hline \multirow[t]{4}{*}{ 5-Emmer et al. (2008)+ } & \multirow[t]{4}{*}{34} & \multirow{4}{*}{$\begin{array}{l}\text { Not included as the four most } \\
\text { prevalent ACR criteria for } \\
\text { NPSLE }\end{array}$} & & Cerebrovascular Disease & $14(41)$ \\
\hline & & & & Seizure disorder & $11(32.3)$ \\
\hline & & & & Cognitive Dysfunction & $7(20.5)$ \\
\hline & & & & Headache disorders & $6(17.6)$ \\
\hline \multirow[t]{4}{*}{ 6-Harboe et al. (2008) } & \multirow[t]{4}{*}{68} & & & Cognitive dysfunction & $38(55.8)^{*}$ \\
\hline & & & & Mood disorder & $26(38.2)^{*}$ \\
\hline & & & & Headache disorder & $18(26.4)^{*}$ \\
\hline & & polyneuropathy & $18(26.4)^{*}$ & & \\
\hline \multirow[t]{4}{*}{ 7-Podrazilová et al. (2008) } & \multirow[t]{4}{*}{29} & Not included as the four most & & Headache disorder & $11(38)$ \\
\hline & & prevalent ACR criteria for & & Psychosis & $9(31)$ \\
\hline & & NPSLE & & Cerebrovascular Disease & $8(27.58)$ \\
\hline & & & & Cranial Neuropathies & $6(20.68)$ \\
\hline 7-Cho et al. (2007) & 25 & Not included as the four most & & Mood Disorder (Major Depression, Depressive features, Manic features, Mixed features) & $8(32)$ \\
\hline & & prevalent ACR criteria for & & Seizure & $8(32)$ \\
\hline & & NPSLE & & Cerebrovascular disease & $5(20)$ \\
\hline & & & & Cognitive dysfunction & \\
\hline & & & & Headache disorders (Migrain, Tension, Cluster, Pseuditumor cerebri, Nonspecific) & $3(12)$ \\
\hline 8-Ainiala et al. (2004)+ & 44 & Not included as the four most & & Cognitive dysfunction & $11(24)$ \\
\hline & & prevalent ACR criteria for & & Cerebrovascular disease & $7(15)$ \\
\hline & & NPSLE & & Seizure disorder Acute Confusional state & $4(9)$ \\
\hline & & & & & $3(7)$ \\
\hline 9-Cotton et al. (2004) & 30 & Not included as the four most & & Acute Confusional State & $7(23.3)$ \\
\hline & & prevalent ACR criteria for & & Headache disorder & $6(20)$ \\
\hline & & NPSLE & & Cerebrovascular disease & $3(10)$ \\
\hline & & & & Cognitive Dysfunction/Mood disorder & $2(6.6)$ \\
\hline 10-Sanna et al. (2003)+ & 323 & Not included as the four most & & Headache & $78(24)$ \\
\hline & & prevalent ACR criteria for & & Cereebrovascular disorder & $57(176)$ \\
\hline & & NPSLE & & Mood disorder & $54(16.7)$ \\
\hline & & & & Cognitive dysfunction & $35(10.8)$ \\
\hline 11-Wilmer et al. (2003) & 28 & Not included as the four most & & Cognitive disorder & $22(78)^{*}$ \\
\hline & & prevalent ACR criteria for & & Mood disorder & $16(59)^{*}$ \\
\hline & & NPSLE & & Seizure disorder & $11(41)^{*}$ \\
\hline & & & & $\begin{array}{l}\text { Headache } \\
\text { Hat }\end{array}$ & $9(33)^{*}$ \\
\hline 12-Kumral et al. (2002)- & 25 & Not included as the four most & & Depression & $14(56)$ \\
\hline & & prevalent ACR criteria for & & Stroke & $1(4)$ \\
\hline & & NPSLE & & Seizures & $1(4)$ \\
\hline & & & & Psychosis & $1(4)$ \\
\hline 13- Karassa, et al. $(2000)^{+}$ & 32 & Not included as the four most & & Cerebrovascular disease & $9(28.1)$ \\
\hline & & prevalent ACR criteria for & & Seizures & $8(25)$ \\
\hline & & NPSLE & & Acute confusional state/ & $6(18.7)$ \\
\hline & & & & Psychosis/Headache/cranial Neuropathies/Demyelinating syndrome/Cognitive Dysfunction & $3(9.3)$ \\
\hline 14- Podrazilová et al. (2008) + & 29 & Not included as the four most & & Headache & $11(38)$ \\
\hline & & prevalent ACR criteria for & & Psychosis & $9(31)$ \\
\hline & & NPSLE & & Cerebrovascular disease & $8(27.58)$ \\
\hline & & & & Seizure disorder & $8(27.58)$ \\
\hline
\end{tabular}

Note. + studies that characterize the participants according to the 19 ACR neuropsychiatric syndromes; - studies that did not characterize the sample according to the 19 ACR neuropsychiatric syndromes. 
ACR criteria identified by the 14 neuroimaging studies were, seizure/cerebrovascular disease $(85.71 \%)^{2,18,22,25-27,29-32,34}$, the most prevalent; followed by cognitive dysfunction $(78.57 \%)^{2,18,22,24,25,27,29-31,34}$ and headache $(78.57 \%)^{2,18,22,24-}$ $27,29,31,34$ then by mood disorder $(57.14 \%)^{22,24,27,29,31,32,36,37}$; psychosis $(28.57 \%)^{2,26,32,34}$; acute confusional state $(21.42 \%)$ $29,30,34$, cranial neuropathies $(14.28 \%)^{26,34}$; stroke $^{32}$ and demyelinating syndromes $(7.14 \%)^{34}$.

Neuropsychological functions most frequently assessed by the studies were concentrated attention $(33.33 \%)^{21-24,31,32,36}$, cognitive flexibility $(28.57 \%)^{23,24,31,32}$, visual episodic memory $(28.57 \%)^{23,24,31,32}$, processing speed $(28.57 \%)^{23,24,31,32}$ and verbal episodic memory $(23.81 \%)^{22,24,32}$, as can be seen in Table 4 . The frequency was calculated considering that each article and instrument could have assessed one or more cognitive function. The most used neuropsychological tests, aiming to assess different cognitive components, were: Rey Complex figure, Stroop Color and Word Test, Mini-Mental State Auditory Verbal Learning Test.

\section{Discussion}

This systematic review showed some important issues to better understand the main classification criteria and assessment methods used to differentiate NPSLE from non-NPSLE samples in neuroimaging studies. In regard to the criteria and evaluation procedures used to characterize the samples, more than half of the articles from this present review had classified their neuropsychiatric samples according to the recommendations of 1999 ACR NPSLE criteria ${ }^{1}$. However, only three of these articles $24,31,37$ fully described the ACR recommendations including laboratorial, clinical, neurological/neuroimaging, as well as cognitive and psychiatric/functional evaluations ${ }^{3}$. Among the ones that employed cognitive assessment, less than half used the same or similar instruments to the neuropsychological battery recommended by ACR. Several of these studies did not describe whether they used cognitive measurements. Furthermore, a couple of these studies used only two instruments in which one of them was the Mini Mental State Examination.

Although the ACR criteria developed a system in which researchers could have one name for each of 19 neuropsychiatric syndromes to advance knowledge and investigation of this pathology $\mathrm{y}^{3}$, there are still a large number of studies, as shown in this review, which do not totally benefit from the ACR nomenclature. Neuroimaging studies have used different definitions of NP syndromes and presented lack of evaluation descriptions, methodological heterogeneity of design, with some of them being based on retrospective chart reviews, and all of these factors have contributed to important limitations in this field ${ }^{6}$. There is still a large discrepancy amongst neuroimaging studies that can be strongly related to not following all of the recommendations for NPSLE of ACR.

Among the 19 neuropsychiatric syndromes from ACR, it was observed that even though the studies included in this review were not necessarily trying to investigate the prevalence of these syndromes, most of them had reported the most frequent NP manifestations. The most prevalent syndrome in this review was seizure/cerebrovascular disease; this result may be related to the neuroimaging exam sensitivity to capture alterations in the white matter. Accordingly with clinical diagnosis, cognitive

\section{Table 4: Frequency of cognitive functions assessed}

\begin{tabular}{lc}
\hline Cognitive function & Number of articles \\
\hline Attention - Concentrated & 7 \\
Cognitive flexibility & 6 \\
Episodic memory - Visual & 6 \\
Processing speed & 6 \\
Episodic memory - Verbal & 5 \\
Inhibition & 4 \\
Praxis & 4 \\
Attention - Alterned & 3 \\
General cognitive status & 3 \\
IQ & 3 \\
Visuo-spatial and motor functioning & 3 \\
Working memory & 2 \\
Attention - Not specified & 1 \\
Language & 1 \\
Lexical-semantic access & 1 \\
Naming & 1 \\
Reading & 1 \\
Semantic memory & 1 \\
Verbal planning & 1
\end{tabular}

Note. Most articles investigated more than one cognitive function.

dysfunctions as well as headache disorder were reported in more than half of these investigations. Unlike the results of this review, several studies have highlighted cognitive dysfunction as one of the most common NP manifestations followed by headaches $7,18,21$. Even though these two syndromes were not reported as the most frequent ones in this review, they were still highly classified. The high frequency of cognitive dysfunctions can be related to the fact that most of the neuropsychiatric syndromes classified by the ACR may affect the central nervous system, causing cognitive alterations ${ }^{7}$. In regard to the other syndromes, mood disorders were present in approximately half of the studies and the least prevalent ones were stroke and demyelinating syndromes. Although the ACR criteria for the 19 NPSLE syndromes also include disorders of the peripheral nervous system, they were not added in this review due to the selection of studies that have been in neuroimaging.

Formal neuropsychological assessments have not been used routinely in these neuroimaging studies, possibly for logistical reasons, as there is currently no validated universally accepted screening tool for cognitive dysfunction regarding each probable impaired component in SLE. The Mini-Mental Status Examination that has been used quite often, is not sufficiently sensitive to measure specific cognitive deficits in this population $^{6}$. Moreover, cognitive dysfunction may vary over time in patients with NPSLE, and standardized cognitive instruments may contribute to identification of cognitive status of these patients over time. However, it is crucial that cognitive test results be interpreted based on normative data appropriate for age, education, sex, and ethnic group ${ }^{3}$. Standardized neuropsychological tests are noninvasive tools that can evaluate the effect of SLE on the brain. They can be used as a follow-up 
or to monitor alterations or progress of the disease. In addition, it can be very useful to measure treatment outcomes ${ }^{1}$. Usually most studies do not use these guidelines as Kozora et $\mathrm{al}^{15}$ did. Their study found that the ACR-SLE neuropsychological battery is valid and reliable ${ }^{15}$, even though constant development of new batteries or investigation about accuracy for diagnosis in SLE patients of existing batteries is the focus of several studies ${ }^{10}$.

Regarding the frequency of test utilization and assessed cognitive processes, sustained attention, cognitive flexibility, verbal and visual episodic memory and processing speed have been more focused. Amongst the main assessment methods, sustained attention was investigated mainly by means of bi and tripartite paradigms (such as Digit Span, Trail Making Test and Stroop Color and Word test), which were developed to measure components of executive function; episodic memory was assessed through classical paradigms of Rey Complex Figure and Auditory Verbal Learning, which are highly sensitive but at the same time do not use verbal complex stimuli, such as discourse; and processing speed was indirectly evaluated through tasks that required mostly focused attention, praxis and executive functions, which requires careful interpretation of results mainly when motor output is required. In general, it is noteworthy to point out assessment methods in these studies are mainly standardized and inherently artificial tools, lacking of ecological approaches.

Characterization of cognitive impairment is still a challenge, when the complexity of the disease in its physical and emotional aspects is considered. However, many studies suggest these cognitive functions are also the most frequent or significantly impaired $^{38-40}$, and that some deficits are present even when psychological and emotional aspects are controlled ${ }^{36}$. In Olazarán et $\mathrm{al}^{39}$ language function showed a high rate of impairment, especially in language comprehension, notwithstanding the findings of the present research pointed out that language and communication do not seem to be a priority for most neuroimaging studies investigating SLE. This review has shown that neuroimaging and neuropsychological measurements are mostly used to characterize NPSLE samples, instead of contributing to the diagnosis of this disease.

In regard to brain imaging techniques, our frequency analysis demonstrated that MRI is the most used neuroimaging procedure in the neurological assessment of NP in SLE patients. This technique is able to visualise common lesions found in SLE patients, such as atrophy, hemorrhage, focal and diffuse hyperintensities ${ }^{34}$. A challenge in the use of this method is that it is not always correlated with clinical symptoms, and might indicate gaps in the diagnostic understanding of the mechanisms of $\mathrm{SLE}^{11}$. Although this technique may indeed be sensitive, this sensitivity and recent developments by no means makes them a standard of care for NPSLE at the present time.

It has being observed, however, that few studies have utilized more advanced neuroimaging techniques to investigate other aspects than lesion location that might be of interest for the comprehension of functional or structural-related organization of cognitive functioning ${ }^{41}$. Few studies administered DTI, for example, illustrating that, in spite of recent evidence of the sensitivity of these techniques and the relationship between white matter damage and other clinical variables of the disease, such as medications ${ }^{42}$, studies still favor traditional techniques instead of advanced ones. This present systematic review will not discuss the peripheral nervous syndromes from the 19 NPSLE ACR classifications, due to our selection of only neuroimaging studies, which was one of our limitations.

Considering the remaining limitations in the field investigating NPSLE, some of these seem to need more specific solutions. The 19 NP syndromes or even others still not officially recognized can be assessed by means of standardized and specifically validated, cognitive assessments and imaging techniques based on discriminating findings that could accurately differentiate NPSLE from non-NPSLE. Among these assessment procedures, in order to solve the confounding variables, one of the possible solutions could be to assess the performance and functional impact of the neuropsychiatric syndromes in SLE, exploring together the neural correlates by means of advanced neuroimaging techniques. However, while some of these techniques may indeed be sensitive, their sensitivity and recent development by no means makes them a standard of care for NPSLE at the present time. In summary, the ACR system seems to be the best way to classify neuropsychiatric syndromes associated with SLE, although the application of neuropsychological and neuroimaging procedures seems to still not be frequently present in neuroimaging studies as recommended by ACR, 1999. In this review, we have focused on methodological issues - future studies could explore neuroimaging correlates of NPSLE and include other studies besides neuroimaging to describe how NP syndromes in SLE samples are classified.

\section{ACKNOWLEDGEMENTS}

The authors thank the Conselho Nacional de Desenvolvimento Científico e Tecnológico (CNPq) of the Brazilian Government for providing financial support for the authors who participated in this research project.

\section{REFERENCES}

1. Bruns A, Meyer O. Neuropsychiatric manifestations of systemic lupus erythematosus. Joint Bone Spine. 2006;73:639-45.

2. Luyendijk J, Steens SCA, Ouwendijk WJN, et al. Neuropsychiatric systemic lupus erythematosus: lessons learned from magnetic resonance imaging. Arthritis Rheum. 2011;63(3):722-32.

3. ACR Ad Hoc Committee on Neuropsychiatric Lupus Nomenclature. The American College of Rheumatology nomenclature and care definitions for neuropsychiatric lupus syndromes. Arthritis Rheum. 1999;42:599-608.

4. Helmick CG, Felson DT, Lawrence RC, et al. Estimates of the prevalence of arthritis and other rheumatic conditions in the United States. Arthritis Rheum. 2008;58(1):15-25.

5. Hanly JG. Neuropsychiatric lupus. Curr Rheumatol Rep. 2001;3(3): 205-12.

6. Hanly JG, Urowitz MB, Sanchez-Guerrero J, et al. Neuropsychiatric events at the time of diagnosis of systemic lupus erythematosus: an international inception cohort study. Arthritis Rheum. 2007;56(1):265-73.

7. Hermosillo-Romo D, Brey RL. Neuropsychiatric involvement in systemic lupus erythematosus. Curr Rheumatol Rep. 2002;4(4): 337-44.

8. Spinosa MJ, Bandeira M, Liberalesso PB, et al. Clinical, laboratory and neuroimage findings in juvenile systemic lupus erythematosus presenting involvement of the nervous system. Arq Neuropsiquiatr. 2007;65(2B):433-9.

9. Afeltra A, Garzia P, Mitterhofer AP, et al. Neuropsychiatric lupus syndromes: relationship with antiphospholipid antibodies. Neurology. 2003;61(1):108-10. 
10. Adhikari T, Piatti A, Luggen M. Cognitive dysfunction in SLE: development of a screening tool. Lupus. 2011;20(11):1142-6.

11. Peterson PL, Howe FA, Clark CA, Axford JS. Quantitative magnetic resonance imaging in neuropsychiatric systemic lupus erythematosus. Lupus. 2003;12:897-902.

12. Appenzeller S, Pike GB, Clarke AE. Magnetic resonance imaging in the evaluation of central nervous system manifestations in systemic lupus erythematosus. Clinic Rev Allerg Immunol. 2008;34:361-6

13. Borchers AT, Aoki CA, Naguwa SM, Keen CL, Shoenfeld Y, Gershwin ME. Neuropsychiatric features of systemic lupus erythematosus. Autoimmun Rev. 2005;4(6):329-44.

14. Appenzeller S, Cendes F, Costallat LTL. Cognitive impairment and employment status in systemic lupus erythematosus: a prospective longitudinal study. Arthritis Care Res. 2009;61(5): $680-7$

15. Kozora E, Brown MS, Filley CM, et al. Memory impairment associated with neurometabolic abnormalities of the hippocampus in patients with non-neuropsychiatric systemic lupus erythematosus. Lupus. 2011;20(6):598-606.

16. Hanly J G. ACR classification criteria for systemic lupus erythematosus: limitations and revisions to neuropsychiatric variables. Lupus. 2004;13:861-4

17. Unterman A, Nolte JE, Boaz M, Abady M, Shoenfeld Y, ZandmanGoddard G (2011). Neuropsychiatric syndromes in systemic lupus erythematosus: a meta-analysis. Semin Arthritis Rheum. 2011;41(1):1-11.

18. Emmer BJ, van Osch MJ, Wu O, et al. Perfusion MRI in neuropsychiatric systemic lupus erthemathosus. J Magn Reson Imaging. 2010;32(2):283-8.

19. Berlit P. Neuropsychiatric disease in collagen vascular diseases and vasculitis. J Neurol 2007;254(2):II/87-II/89.

20. Popescu A, Kao AH. Neuropsychiatric systemic lupus erythematosus. Curr Neuropharmacol. 2011;9(3):449-57.

21. Azarpazhooh MR, Mokhber N, Orouji E, et al. Microembolic signals in patients with systemic lupus erythematosus. Can J Neurol Sci. 2010;37(3):371-5.

22. Davey R, Bamford J, Emery P. The role of endothelial dysfunction in the pathogenesis of neuropsychiatric systemic lupus erythematosus. Lupus. 2010;19(7):797-802.

23. Whitelaw DA, Spangenberg JJ. An investigation in the possible effect of chronic headache on neuropsychological function in aCL-negative patients with SLE. Lupus. 2009;18(7):613-17.

24. Harboe E, Tjensvoll AB, Maroni S, et al. Neuropsychiatric syndromes in patients with systemic lupus erythematosus and primary Sjögren syndrome: a comparative population-based study. Ann Rheum Dis. 2009;68(10):1541-6.

25. Emmer BJ, Steup-Beekman GM, Steens SC, et al. Correlation of magnetization transfer ratio histogram parameters with neuropsychiatric systemic lupus erythematosus criteria and proton magnetic resonance spectroscopy: association of magnetization transfer ratio peak height with neuronal and cognitive dysfunction. Arthritis Rheum. 2008;58(5):1451-7.

26. Podrazilová L, Peterová V, Olejárová M, et al. Magnetic resonance volumetry of pathological brain foci in patients with systemic lupus erythematosus. Clin Exp Rheumatol. 2008;26(4):604-10.
27. Cho BS, Kim HS, Oh SJ, et al. Comparison of the clinical manifestations, brain MRI and prognosis between neuroBeçhet's disease and neuropsychiatric lupus. Korean J Intern Med. 2007; 22(2):77-86.

28. Roldan CA, Gelgand EA, Qualls CR, Sibbitt WL Jr. Valvular heart disease is associated with nonfocal neuropsychiatric systemic lupus erythematosus. J Clin Rheumatol. 2006;12(1):3-10.

29. Cotton F, Bouffard-Vercelli J, Hermier M, et al. MRI of central nervous system in a series of 58 systemic lupus erythematosus (SLE) patients with or without overt neuropsychiatric manifestations. Rev Med Interne. 2004;25(1):8-15.

30. Ainiala H, Hietaharju A, Dastidar P, et al. Increased serum matrix metalloproteinase 9 levels in systemic lupus erythematosus patients with neuropsychiatric manifestations and brain magnetic resonance imaging abnormalities. Arthritis Rheum. 2004;50(3): 858-65.

31. Sanna G, Bertolaccini ML, Cuadrado MJ, et al. Neuropsychiatric manifestations in systemic lupus erythematosus: prevalence and association with antiphospholipid antibodies. J Rheumatol. 2003;30(5):985-92.

32. Kumral E, Evyapan D, Keser G, et al. Detection of microembolic signals in patients with neuropsychiatric lupus erythematosus. Eur Neurol. 2002;47(3):131-5.

33. Lampropoulos CE, Koutroumanidis M, Reynolds PP, et al. Electroencephalography in the assessment of neuropsychiatric manifestations in antiphospholipid syndrome and systemic lupus erythematosus. Arthritis Rheum. 2005;52(3):841-6.

34. Karassa FB, Ioannidis JP, Boki KA, et al. Predictors of clinical outcome and radiologic progression in patients with neuropsychiatric manifestations of systemic lupus erythematosus. Am J Med. 2000;109(8):628-34.

35. Tatsukawa $H$, Ishii $K$, Haranaka $M$, et al. Evaluation of average amount of cerebral blood flow measured by brain perfusion index in patients with neuropsychiatric systemic lupus erythematosus. Lupus. 2005;14(6):445-9.

36. Sibbitt WL Jr, Schmidt PJ, Hart BL, Brooks WM. Fluid Attenuated Inversion Recovery (FLAIR) imaging in neuropsychiatric systemic lupus erythematosus. J Rheumatol. 2003;30(9):1983-9.

37. Walecki J, Sierakowski S, Lewszuk A, et al. MR in neurological syndromes of connective tissue diseases. Med Sci Monit. 2002;8 (6):105-11.

38. Julian LJ, Yelin E, Yazdany J. Depression, medication adherence, and service utilization in systemic lupus erythematosus. Arthritis Care Res. 2009;61(2):240-6.

39. Olazarán J, López-Longo J, Cruz I, et al. Cognitive dysfunction in systemic lupus erythematosus: prevalence and correlates. Eur Neurol. 2009;62:49-55.

40. Vogel A, Bhattacharya S, Larsen JL, Jacobsen S. Do subjective cognitive complaints correlate with cognitive impairment in systemic lupus erythematosus? A Danish outpatient study. Lupus. 2011;20:35-43

41. Lee KL, Mok CC. Role of neuroimaging in the management of neuropsychiatric lupus. Hong Kong Bull Rheum Dis. 2004;4(1): 26-30.

42. Jung RE, Caprihan A, Chavez RS, et al. Diffusion tensor imaging in neuropsychiatric systemic lupus erythematosus. BCM Neurol. 2010;10(65):1-9. 